\title{
Pluralism Based Religious Education for Deradicalization of Religion
}

\author{
Abdul Rohman \\ FITK UIN Walisongo Semarang \\ rahman_1969@yahoo.co.id
}

\begin{abstract}
Radicalism has recently become a phenomenon. Violences in some areas of Indonesia is a proof. These violences are caused by the conflict that is be partly due to a plurality. These problems have to be overcome in order to shape the unity of the nation. This study will discuss the role of schools in developing the diversity of students in response to the religious plurality in society, which will be focused on how the curriculum is constructed, teaching-learning is done, as well as how the teacher and student's understanding on religious pluralism is, as a result of the education process. With a qualitative research, a case study in SMA Madania Bogor West Java, this study shows that school with a pluralistic based religious education, fits for internalizing the values of pluralism, in turn forming tolerances and inclusiveness.
\end{abstract}

\begin{abstract}
Abstrak
Radikalisme telah menjadi fenomena akhir-akhir ini. Sejumlah kekerasan di beberapa daerah Indonesia merupakan bukti akan hal itu. Peristiwa-peristiwa tersebut terjadi di antaranya karena konflik dikarenakan faktor pluralitas. Persoalan-persoalan ini bila tidak diatasi, akan mengganggu persatuan dan kesatuan bangsa. Kajian ini akan membahas peran sekolah dalam mengembangkan keberagamaan siswa dalam merespon kenyataan pluralitas keagamaan di masyarakat, yang akan difokuskan pada bagaimana kurikulum dikonstruksi, pembelajaran dilakukan, dan kondisi. Dengan pendekatan kualitatif, studi kasus di SMA Madania Bogor Jawa Barat, studi ini menunjukkan bahwa sekolah yang menerapkan pendidikan agama berbasis pluralistik, cocok untuk menanamkan nilai-nilai pluralisme sehingga membentuk sikap toleransi dan inklusivitas siswa.
\end{abstract}

Keywords; Radicalism; Pluralism; Religious Education; Teaching; Value Education 


\section{A. Introduction.}

Radicalism has recently become a phenomenon. As a phenomenon, radicalism has occurred in almost all parts of the world, including in Indonesia. Some violence in some areas of Indonesia: Sambas, Banyuwangi, Situbondo, Poso, Ambon, church bombings, burning mosques, the Bali bombing, violence against Ahmadiyya in Parung, Lombok and Brass, disputes the establishment of houses of worship and acts of violence in Bekasi Regency, some cases in Bogor, Makassar, West Sumatra, Aceh, Lampung and Purbalingga ${ }^{1}$, are a proof. Although the "religion" is not a single factor, but religion is the most sensitive sentiment of the appearance of a conflict that led to the violence. ${ }^{2}$ These problems, not addressed, would disrupt the unity of the nation. Many attempts have been made to overcome it, but the conflict still appears. Susetiawan's ${ }^{3}$, Susan's ${ }^{4}$, Afrizal's ${ }^{5}$, Siahaan's ${ }^{6}$ and Yuwinanto's ${ }^{7}$ studies has proven this case.

This chaoses happened because of the long conflict that is due to a plurality. Indonesia is a pluralistic country, both in ethnicity, religion, race,

\footnotetext{
${ }^{1}$ Suhadi Cholil et. al. Laporan Tahunan Kehidupan Beragama di Indonesia 2012. Yogyakarta: Central for Religious Cross-cultural Studies (CRCS) UGM. 2013, pp. 5354.

${ }^{2}$ Radicalism has become a phenomenon of religions in various parts of the world. It is not only labeled to Islam, but also other religions, such as Christianity, Judaism, Hinduism and Buddhism. In Hinduism, the violence encountered in the case of religious violence in South India, the Sikhs bow hard with Islam. In Israel, there is religious violence between the Jews of Holland with Muslims. In Japan, there is violence in the form of irregularities Shinto religion other wounded. In Christianity, there is violence in the United States and other parts of Europe. In Islam, there are terrors either directly or indirectly that harm others.
}

${ }^{3}$ Susetiawan. Konflik Sosial, Kajian Sosiologis Hubungan Buruh, Perusahaan dan Negara di Indonesia. Yogyakarta: Pustaka Pelajar, 2000.

${ }^{4}$ N. Susan. Sosiologi Konflik dan Isu -Isu Konflik Kontemporer. Jakarta: Prenada Media Group, 2009, p. 5

${ }^{5}$ Afrizal. "Negara dan Konflik Agraria: Studi Kasus pada Komunitas Pusat Perkebunan Kelapa Sawit Berskala Besar di Sumatera Barat". Masyarakat, Kebudayaan dan Politik. 20 (3), 2007, pp. 89-107.

${ }^{6} \mathrm{H}$. Siahaan. "Karakteristik dan Faktor Pemicu Konflik di Daerah Jawa Timur". Masyarakat, Kebudayaan dan Politik. 15(1), 2002, pp. 55-64.

${ }^{7}$ H.P.Yuwinanto. “Konflik Antar Etnik di Pedesaan”. Masyarakat, Kebudayaan dan Politik. 17 (3), 2004, pp.103-107. 
culture, and language. ${ }^{8}$ Therefore it has to be managed well, in order to not cause a conflict. Pluralism should be early introduced to the students, so that the tolerance values can be internalized to them as soon as possible. Education is an important instrument to resolve these conflicts through the cultivation of the values of pluralism and tolerance. Schools have a role in shaping the people's way of thinking. The school is one of the strategic pillars of education in socializing the values of tolerance, moderation, respect, empathy, and developing an attitude of non-violence for learners in responding to the pluralism. Schools not only serves the transfer of skills and knowledge, but also conducts internalizing values to the students. ${ }^{9}$

This study will discuss qualitatively with the case study the role of schools in developing the diversity of students in response to the religious plurality in society, which focuses on how the curriculum is constructed, instruction is done, the infrastructure laid out, and the elements of the school is conditioned for the sake of creating a school culture for holding education that addresses pluralistic values.

\section{B. Pluralism as a basis for Religious Education. 1. Pluralism of Religion.}

Pluralism is derived from the word "plural" that means diverse and "ism" means ideology, so pluralism means ideology of the state of a pluralistic society. Pluralism defined "a framework of interaction in the which groups show sufficient respect and tolerance of each other, that they fruitfully interact without conflict or assimilation." Imarah ${ }^{10}$ defines that religious pluralism is diversity that is based on

\footnotetext{
${ }^{8}$ Koentjaraningrat stated that Indonesia ethnically has more than 151 ethnics who live from Sabang to Merauke. Religiously, Indonesia recognizes many religions, such as: Islam, Catholic, Christian, Hindu, Buddhist, as weel as a range of local religions who live in the society. In terms of language, the Indonesian is as the national language, and a different dialect and local language. See Misbah Zulfa Elizabeth. "Multi-Ethnicity Indonesia and Potential Conflicts in it" See Misbah Zulfa Elizabeth. "Multi Etnisitas Indonesia dan Potensi Konflik di dalamnya", dalam Musahadi HAM (Ed.). Mediasi dan Resolusi Konflik di Indonesia: dari Konflik Agama hingga Mediasi Peradilan. Semarang: Mediation Centre, 2007, p. 5.

${ }^{9}$ Abdurrahman Mas'ud. Menggagas Format Pendidikan Non Dikotomik: Humanisme Religius sebagai Paradigma Pendidikan Islam. Yogjakarta: Gama Media, 2002; juga A.Qodry A. Azizy. Pendidikan (Agama) untuk Membangun Etika Sosial: Mendidik Anak Sukses Masa Depan, Pandai dan Bermanfaat. Semarang: Aneka Ilmu, 2002.

${ }^{10}$ Anis Malik Thoha. Tren Pluralisme Agama: Tinjauan Kritik. Jakarta: Perspektif Kelompok Gema Insani, 2007, p. 129.
} 
the specificity characteristics. Madjid ${ }^{11}$ explained that religious pluralism can be taken through the three religious attitudes, namely: the exclusive, inclusive, and pluralist one. With these attitude, other religions have the equally legitimate to achieve the same truth in different ways. Madjid ${ }^{12}$ also asserted that religious pluralism is not only understood as a plural society, diverse, consisting of various races and religions, but also it should be understood as genuine engagement of diversities within the bond of civility. While Shihab ${ }^{13}$ stated that believers demanded not only recognizes the existence and rights of other religions, but also involved in the effort to understand the differences and similarities in order to achieve harmony and diversity.

Historically, religious pluralism emerged in the Enlightenment of the 18th century $\mathrm{AD}$, the starting point of the rise of modern thought ${ }^{14}$, namely the time tinged with new discourses of human thought that oriented superiority and liberationof from the shackles of religion. Amid in the European idea as a logical consequence of the conflicts that occur between the church and the outside, there arose a notion known as "liberalism"15, which is the demanded a freedom, tolerance, equality and diversity or pluralism. ${ }^{16}$ When entering the 20th century, the idea of religious pluralism got in the discourse of philosophy and theology of the West, with figures such as Ernst Troeltsch (1865-1923), William E.Hocking (1932), Arnold Toynbee (1889-1975) ${ }^{17}$, theologians and religious historians Canada, Wilfred Cantwell Smith. He provided the concept of universal or global theology as a common ground of the world religions to interact peacefully and harmoniously. ${ }^{18}$ The idea of religious pluralism reached its maturity phase in the last two decades of the 20th century,

\footnotetext{
${ }^{11}$ Nurcholish Madjid. Mencari Akar-Akar Islam bagi Pluralisme Modern: Pengalaman Indonesia dalam Jalan Baru. Bandung: Mizan, 1998, p. 56.

${ }^{12}$ Budhi Munawar Rachman. Islam Pluralis. Jakarta: Paramadina, 2001, p. 39.

${ }^{13}$ Alwi Shihab. Islam Inklusif Menuju Sikap Terbuka. Bandung: Mizan, 1999, p. 41.

${ }^{14}$ Anis Malik Thoha. Tren..., p. 16.

${ }^{15}$ Ibid., p. 17. See a complete discussion on liberalism in De Ruggiero Guuido, 'Liberalism" in Seligmen Edwin R.A. Encyclopedia of Social Science. New York: The Maccmillan Company, 1933

${ }^{16}$ Anis Malik Thoha. Tren..., p.17.

${ }^{17}$ Ibid. p. 18 .

${ }^{18}$ Ibid., p. 19.
} 
developed by the thinkers John Hick ${ }^{19}$ who reconstructed the theoretical foundations of religious pluralism.

The earlier time of religious pluralism has actually appeared in India in the late 15th century under Kabir (1440-1518), and Guru Nanak (1469-1538) founder of the religion 'Shikisme" ${ }^{20}$ in India. When globalization gets stronger, and the development of new approaches of scientific study of religion increasingly spread, the idea of religious pluralism is widely recognized. ${ }^{21}$ So the idea of religious pluralism is not only Western thought, but also has been strongly rooted from the Eastern thinkers, especially India. ${ }^{22}$ But in the discourse of Islamic thought, it is still a novelty and lacked ideologically and theologically. ${ }^{23}$ In Islam, this religious pluralism is a new perspective as the penetration process of West culture in the Islamic world, which emerged in the period after the Second World War, when West give opportunities for young Muslims to study in Western universities, so they can acquainted with Western culture. ${ }^{24}$

\footnotetext{
${ }^{19}$ Anis Malik Thoha states that John Hick is the only modern theologians who gives a deep concern for religious pluralism. He has poured his thoughts into 30 books or papers that explore religious pluralism. One of them is 'an interpretation of religion: Human Responsess to the Transcendent" the work that is lifted from his lecture series on the theme Giffort Lecture in 1986-1987..

${ }^{20}$ Anis Malik Thoha. Tren... p 20.

${ }^{21}$ Ibid. hal. 20.

${ }^{22}$ Some Western scholars such as Parrinder and Sharpe claimed that the originator of the idea of religious pluralism are the thinkers of the Indian. Both mention the name of Ram Mohan Roy (1772-1833) as the originator of the Brahmo Samaj movement which was originally Hindu, learns the concept of God of Islam, then trigger the thoughts of God and religious equality. In addition, Sri Ramakrishna (1834-1886) who has thought about friendship and tolerance between religions is full, then continued Keshab Chandra Sen (1838-1884), Swami Vivekananda (1882-1902), Mahatma Gandhi (1869-1948), and Sarvapalli Radhakrishnan (1888-1975).

${ }^{23}$ Anis Malik Thoha. Tren... p. 23.

${ }^{24}$ Seyyed Hossein Nasr, a moderate Shiite Muslim is a figure who popularized the idea of religious pluralism in Islamic circles. Nasr tried to pour his thesis on religious pluralism in packaging sophia perennis or perennial wisdom (al-hikmah al-Khalidah or eternal truth), which is a discourse revive 'the unity of metaphysical "hidden behind the teachings and religious traditions has ever known since Adam's to the present. See Seyyed Hussein Nasr. Ideal and Realities of Islam. Lahore: Suhail Academic, 1994.
} 


\section{The Role of School in Internalization Values of Religious Pluralism.}

Value as part of an affective domain is very important, even it is more vital than others ${ }^{25}$, and it is a responsible of families, communities and schools. ${ }^{26}$ However, since most parents hand over their children to school, then the school has a higher responsibility. Schools have a role in shaping a thinking frame of the learners. Shane $^{27}$ insists that education has four potential for their future life: Firstly, education provides a vehicle for the implementation of the values in a changing society. Secondly, education can be used to address specific social problems. Thirdly, education increases the ability to accept and implement new alternatives. Fourthly, education is the best way to guide human development to contribute to the culture.

Internalizing values in schools will affect the childern's perceptions, attitudes and behaviors in response to the reality of pluralism. Syahroni ${ }^{28}$ explained that there are three main factors that support the integration of a religious pluralism, namely: (1) understanding a religion which emphasizes the meaning internally and externally. Internal one refers to religious truth he embraced, while external one refers to the understanding that he needs to be respected. (2) having the same common cultural sense. (3) religious and community leaders who accommodate to resolve the conflict between religious groups.

Fadjar and Arifin ${ }^{29}$ states that in social interaction there are two types of social distance that the objective and subjective social distance. Objective social distance occurred because of the

\footnotetext{
${ }^{25}$ Djemari Mardapi. Pengukuran, Penilaian dan Evaluasi Pendidikan. Yogjakarta: Nuha Litera, 2012, p 154; Thomas Lickona. Educating for Character: How Our Schools Can Teach Respect and Responsibilty. New York: Bantam Book, 1992, p. 6.

${ }^{26}$ Oladipo stated that "each child from birth, by virtue of his environment, belongs to a significant group. Familiy members, friends, relatives, teachers and administrators play a major role in formation of the character of each child". See S.E. Oladipo. "Moral Education of the Child: Whose Responsibility?", J Sec Sei, 20, (2), 2009, 149-156

${ }^{27}$ Muqaddimah Jurnal Ulumuddin No. 4 Thn 3, Juni Malang: FAI Univ. Muhammadiyah, 2000 , p. 1.

${ }^{28}$ Syahroni A.J. "Pluralisme Keberagamaan: Wawasan Subyek Dakwah" Jurnal Wacana No. 1, Vol. 3, November 2003. Surabaya: Kopertais Wilayah IV, 2003, p. 100.

${ }^{29}$ A.Malik Fadjar \& Syamsul Arifin. "Muhammadiyah dan Pluralisme Agama” Jurnal Ulumuddin No 1, Thn IV, Juli 2001. Malang: FAI Univ. Muhammadiyah, 2001, p. 6.
} 
geographical situation and the transportation difficulty, religion, ethnicity and socioeconomic status; whereas subjective one occurs because a person's feeling does not want to communicate with other.

Dialogue is also a great instrument to understand the other's religion. The theory of "ten Commandment" from Leonard Swidler ${ }^{30}$ sees that the dialogue is an important medium to foster mutual understanding. With dialogue, people of different faiths can learn good values in any religious teachings. Dialogue does not presuppose the others must have a same vision, but it is started because of a different view. According Swidler, religious pluralism can be solved through the theory of "Ten Commandment" that contains 10 steps, partly consist of: a dialogue with the aim of mutual learning and understanding, dialogue should be honest and sincere, not compare an idealized view to other religions, dialogue should be equal, understand others from the "in", everyone must remain in the authenticity of his religion, the importance of interacting with different communities.

Impementing a theory of Swidler is a "story telling" as stated Patel, Eboo, April Kunzo, and Noah Silverman. ${ }^{31}$ With the "story telling", the teens try to learn and appreciate the spiritual experience happened to his friend of another faith. Interreligious dialogue is not meant for the "conversion" of religion, but to build openness, sincerity and mutual trust as a starting point in responding to various humanitarian issues. Interfaith harmony that is separated from the humanism commitment, it is an artificial harmony. ${ }^{32}$

\section{Deradikalisalion: Pluralism Based Religious Education. 1. Madinah as a philosopical Bases of the Pluralism.}

Madania's Indonesian Education Foundation (YPMI) was established in $1995^{33}$ by the founders: Nurcholish Madjid, Achmad Fuadi, and Komaruddin Hidayat. Madania name comes from the

\footnotetext{
${ }^{30}$ Leonard Swidler. "The Dialogue Decalogue; Ground Rules for Interreligious, Interidioligical Dialogue", Journal of Ecumenical Studies. Vol. 20 (01). 1984.

${ }^{31}$ Fatimah Huseen. "Merangkul yang Lain" in Hendri Wijayatsih et.al.. Memahami Kebenaran yang Lain sebagai Pembaharuan Hidup Bersama. Yogyakarta: Taman Pustaka Kristen, 2009.

${ }^{32}$ J.B. Banawiratma \& Zainal Abidin Bagir. Dialog Antarumat Beragama: Gagasan dan Praktik di Indonesia. Bandung: Mizan, 2010.

${ }^{33}$ Tim. Madania Indonesian School With World Class Sandard. Bogor. Madania, t.t. , p. 3.
} 
Arabic "Madaniah", rooted the word "Madinah". Madinah means a place of civilization, which is also often interpreted town, which is a place inhabited by a civilized society, full of obedience, discipline, and subject-obedient to God. ${ }^{34}$ Therefore, both "Madaniah" or "medina" is a word derived from the root word "daana, yadiinu, diinan", which means obedient, submissive, obedient and submissive. Madaniah and Medina also derived from the word "madana-yamdunu, madiinah", which means building, namely building a civilization. ${ }^{35}$ With the spirit of these meanings, in 1996 the School of Madania YPMI is founded.

The Madania School is a school that respects differences, respect for the individual with diverse learning. He provides learning experiences in an atmosphere that respects the wisdom Indonesian spirituality, traditions, noble values, art, culture and history of the nation, supported with man power, learning programs and international standard facilities. ${ }^{36}$ Madania's vision is a true Indonesian school for the next generation of leaders. Mission: educating towards Reviving consciousness of God, actualizing world class standards, living with noble character, and respecting Indonesian values. With this vision and mission, the school prepares students become a future leaders who have an awareness of God, internationally-minded, noble character and uphold the noble values and Indonesia traditions. There are some values that were developed in the educational program at Madania, namely: truth, the absolute faiths expressed in the form of efforts to eliminate the ego, so all of thing are the God's will; inclusive, the intention and ability to become a person who received outright differences in religion, beliefs and abilities and uniqueness of self and others; integrity, runs intentions, thoughts, feelings and good and right actions, as well as a commitment to the good and true; care, intentions and caring assist others to carry out the service to all human being. ${ }^{37}$

\footnotetext{
${ }^{34}$ Ibid, p. 3.

${ }^{35}$ Ibid, p. 3.

${ }^{36}$ Ibid, p. 4.

${ }^{37}$ Ibid, pp. 6-7.
} 


\section{Student and Teacher.}

Madania has pluralistic school. It has 294 students that consists of 253 Muslems, 18 Christians, 14 Catholics, 1 Hindu, 4 Buddhists 3 and Jehovah's Witnesses. School provides a various places to performance a ritual in their daily activities. The student can do freely their religious ritual. School also provides the teachers of religion based on the students' religious backgrounds. Students addresses a teaching-learning activities in the religion based on their each religion background.

Teachers' Madania High School numbered 68 peoples. Based on their educational qualification, Diploma-3 educated teachers are 3 peoples, 60 peoples with Bachelor degree 5 peoples with Master degree. Based on their religious belief: moslem teachers are 59, 4 Catholic teachers, 2 Protestant teachers, one Buddhist teacher, one Hinduist teacher, and the Jehovah's Witnesses is one teacher.

These datas illustrate the socio-cultural is formed in the real environment in which people live with their neighbours, close friends, friends and others who have different backgrounds in religion, race, language and others. Internalization of the values of mutually appreciate differences must be instilled early in a self-learners, so truth claims and blame others who differ with him can be eliminated. This concept is needed in our current educational context.

\section{Curriculum.}

SMA Madania implements national curriculum which is enriched with international curriculum ${ }^{38}$ and 21 st century education. ${ }^{39}$ At secondary school level, the curriculum is combined with the IGCSE (International General Certificate of Secondary School) syllabus and AS/A level of the Cambridge International Examination.

\footnotetext{
${ }^{38}$ Enriched with Cambridge curriculum aims to enable students to be globally competitive and able to develop themselves as learners who have such qualities: confidence in working with information and ideas of their own and others' (confident); responsible for themselves, responsible and respectful of others (responsible); reflective learners, develop their ability to learn (reflective); innovative and able to equip themselves for new challenges and the future (innovative); as well as engage in intellectual and social, are ready to make a difference (engaged).

${ }^{39}$ Tim. Madania...,p. 8.
} 
Madania curriculum also integrates music lessons, theatrical arts, physical education, learning skill (study skills), character education and leadership with the latest learning approach. ${ }^{40}$ To measure the level of academic success, students participate in the International Competitions Assessments for Schools (ICAS), UNSW Australia. ${ }^{41}$ Its curriculum is integrated, both subjects and activities, both intellectual, physical, emotional, social and spiritual.

Madania also educates the student to become a long life learner and a highly motivated, confident, independent, ahead thinker, and have a high social consciousness. Each student is encouraged to conduct experiments and research activities, individually or in groups. Student-centered teaching is designed based on the students' individual needs. Madania graduates should be able to understand the basic knowledge of mathematics, science, history, geography, economics, music and art. English language and computer skills are integral parts of the Madania curriculum. In addition, religious education is taught in accordance religious affiliation of students. Students' assessment of character education is not only by teachers at the school but also involves the role of parents at home. ${ }^{42}$

Students who are interested and have a talent in music, art and theater will be encouraged to join in extra-curricular activities such as art clubs, music, dance (traditional and modern), painting, theater, choir, and others. These activities paved the way for students to explore their potential to the maximum. Meanwhile, to help developing sports talent of students, physical education department runs a comprehensive program. Students are encouraged to develop the sports potential in soccer clubs, basketball, volley ball, baseball, badminton, athletic activities, water sports and team games.

\footnotetext{
${ }^{40}$ Ibid, p. 8 .

${ }^{41}$ ICAS is an independent, skills based assessment program which recognizes and rewards student achievement, UNSW Australia.

${ }^{42}$ Tim. Madania..., p. 9.
} 


\section{Teacher's Understanding on Religion Pluralism.}

Gagne $^{43}$, Ronald Brandt ${ }^{44}$, Heyneman and Loxley ${ }^{45}$ asserted that "teachers play an essential role in accompanying every students' learning". Therefore, in order to maximally succeed in their learning process, teachers must be qualified that manifested in their understanding of the teaching materials. It will, in turn, affect the learning process.

In Religious Education, a teaching material includes two aspects, namely knowledge (science) and faith (belief). As knowledge, religious education is similar to other subject, both in the administration aspect, learning tool and the scientific disciplines; but as beliefs, religious education requires total obedience to believers, it is more subjective, non-negotiable, and absolute. In the context of pluralism, how religious communities can receive the values of pluralistic and in turn have the values of tolerance, will be influenced by the interaction between two dimensions, and it is implemented in SMA Madania Bogor.

The good interaction of these two-dimension can be seen from the teacher statements. Teacher of Islamic religious education stated that "religious pluralism is sunatullah, absolutes that can not be avoided wherever we are, so that difference is common in life". Buddhism Teachers stated that "religious pluralism is a notion of plurality, the attitude of recognizing and accepting their differences, and did not dispute the difference, but it does not equate all the beliefs or religion". Teachers of Jehovah's Witnesses, "... the importance of having appreciation for spiritual values". Christian teachers stated that:

Pluralism means a diversity. In context of The religion pluralism, all religions are equal, but all religions should be open to discuss problems from their religion perspective. It is expected that this disclosure will form ethics, morality and

\footnotetext{
${ }^{43}$ Robert M. Gagne. Principles of Instructional Desaign. Orlando: Harcourt Brace Jovanovich College Publisher, 1992, p. 3.

${ }^{44}$ Ronald Brandt. "What Do You Mean Professional'?. Educational Leadership. No. 6, 50, March. 1993.

${ }^{45}$ S.P.Heyneman dan W.Loxley. "The Impact of Primary School Quality on Academic Achievement in 29 High and Low Income Countries". American Journal of Sociology, 88. 1988.
} 
spirituality of pluralistic society. Therefore, a spirit-filled life which appreciates their own religions, and also appreciates the confidence of other religions. Thus, other people with different religions are seen as colleagues, fellow, and relatives who have their own rights as God's creatures.

Answering a question about the diversity of religions, teacher of Islamic stated that "Islam is the only true religion and blessed by God, relying on arguments from al-Quran and al-Hadith." So are the teachers of Christianity, Catholicism, Hinduism, Buddhists, and Jehovah's Witnesses have the same statement about the truth of religion. This is reinforced by a student's statement: "Although there are many religions in Indonesia and every religion teaches different things, we must respect and honor other religions. Teachers teach that Islam is the true religion, but we must not blaspheme the others."

The informant's statement that "the affiliated religion is the only legitimate religion," is in line with the Swidler's theory ${ }^{46}$ that it is almost impossible to theologically express the truth of other religions. As a doctrine, religion has belief dimensions that it is subjective. Moreover, religions contain truth-claims that could potentially lead to conflict, both sociologically and theologically. The meaning of pluralism that informant expressed is more on the meaning of 'tolerance', which implicitly tends to be passive and defensive, in accordance with the meaning of the tolerance itself $f^{47}$, as well as the term 'harmony' which means "good and peaceful", which refers to "respect without knowledge and understanding" towards something that is respected. It is diferent to the religious pluralism of Western thinkers $^{48}$ that require a proactive attitude. In their perspective,

\footnotetext{
${ }^{46}$ Leonard Swidler. "The Dialogue Decalogue; Ground Rules for Interreligious, Interidioligical Dialogue", dalam Journal of Ecumenical Studies. Vol. 20 (01), 1984.

${ }^{47}$ W.J.S. Poerwadarminta. Kamus Umum Bahasa Indonesia. Jakarta: Balai Pustaka, 1984, p. 1084.

${ }^{48}$ Term pluralism in the West has been progressing meaning. It is the same as "democracy", which insists on freedom, tolerance, equality and coexistence. In modern western concept, it is theoretically very gracious, friendly and tolerant, but practically tends to show opposite, namely intolerance, suppressing character and human rights. Muhammad Emirate states, "the West has forced others to follow their culture and thinking, and release their history, culture and intellectual references". West does not want "to let the others to be really other).See Anis Malik Thoha. Tren..., pp. 127-128.
} 
religious differences are not only appreciated and respected, but also to be learned --- if it is possible --- internalized by other believers. Based on the Swidler's Ten Commandment theory ${ }^{49}$, the drive to learn and appreciate other people's religion will grow if they place another religion equal to their own religion.

As a religious doctrine, it is a common in every religion that religious education tends to favour. Durkheim's theory (in Ritzer and Goodman) confirmed that a religion presupposes the existence of "a single moral community" that does is not mix with outside.

In Islam, religious pluralism is the "sunnah illahiyah". In the Qur'an $^{50}$, plurality is a reality that manifests itself and may not be denied, but retains the specific teachings of the religion. Moreover, in the view of Islam, all religions should be protected, and its adherents should be free to perform their religion. However, the concept of religious freedom represents view of life, behavior and mentality of "having a religion". Therefore, according to Amin Abdullah ${ }^{51}$, it is necessary to develop a dialogue among all religions, which reflects the attitudes, behaviors and mentalities of "being religious".

\section{Religion Pluralism in Religious Teaching-Learning.}

In the classroom, SMA Madania implements an active learning. The whole learning process focuses on the student activities, teachers are as facilitators who stimulate students to learn. Teachers and students mutually listen each other, even their opinions are different. The entire educational activities in Madania run equal and democratic among them.

\footnotetext{
${ }^{49}$ Leonard Swidler."The Dialogue..."

${ }^{50}$ Q.S.Hud: 118-119, Al-Maidah: 48 confirms that differences and diversity of the nations, law and philosophy of life is God' willing. Commentators claim that "difference" and "diversity" is as the reason of this creation. In Q.S.Al-Hujurat: 13, declared that all men are equally God's creatures, they have belief (religion), traditions and culture; they have a different view of life, and they live in a variety of tribes, nations and languages. Therefore, how they can each introduce themselves to each other, their way of life, religious beliefs, traditions and culture, through a understandng process ,or exchange a habit. However, In matter of faith, God says in Q.S Al-Imron: 85 "whoever seeks a religion other than Islam, it occasionally will not be accepted (the religion) thereof. And in the hereafter, including those who have lost."

${ }^{51}$ Amin Abdullah. Pendidikan Agama Era Multikulturalisme Multireligius. Jakarta: Pusat Studi Agama dan Peradaban (PSAP) Muhamadiyyah, 2005.
} 
Religious education in Madania is taught in accordance with their the students'. The school provides religious teachers in accordance with the religion the student professed. This is in line with Article 12 paragraph (1) of Act 20 of 2003 on National Education System which explains that "Every student at any academic year will receive religious education in accordance with their religion and taught by the teacher of the same religion." ${ }^{52}$ In addition, at the university level, religious education became compulsory subjects, inspite of citizenship and language courses. ${ }^{53}$

In the context of "how is the implementation of religious pluralism's values in the religious teaching in SMA Madania", the following are the statement of some teachers. Teachers Christianity stated that:

Internalizing the values of religious pluralism in the religious teaching is through: (1) deepening of scripture; (2) sharing and discussing personal life experiences, students, and others about the awareness of the plurality; (3) exploring reality of living in the community; (4) evaluating and reflecting; (5) conducting interactive interreligious activites, such as religious day, community service and social action.

The informant also stated: "Practicing the values of religious pluralism in the religious teaching by modelling who applies the pluralism values that inspires and motivates students to do the same way."

Meanwhile, Jehovah Witnesses Religion teachers claimed that pluralism is applied to "learn some different views and find out the reason." Similar statement was expressed by Islamic teachers, which stated that "teaching and telling various kinds as well as familiarizing students with some existing views".

These statements above imply that in the religious teaching, students accustomed to exchange ideas and views, thought differences. This conception is in line with the Swidler's theory ${ }^{54}$, that the problem of religious pluralism can be solved through "ten

\footnotetext{
${ }^{52}$ UU No.20 Tahun 2003, Sistem Pendidikan Nasional, Pasal 12 ayat 1.

${ }^{53}$ UU No.12 Tahun 2012, tentang Perguruan Tinggi, Pasal 35.

${ }^{54}$ Leonard Swidler. "The Dialogue...,
} 
commandments" that contains 10 steps in interfaith dialogue: the dialogue that aims at learning and understanding mutually, the dialogue should be honest and sincere, not comparing individual's idealized view with the practice of other religions; dialogue should be similar, understanding others "inwardly", everyone must remain in the authenticity of his religion, the importance of interacting with different communities. Furthermore, Banawiratma \& Bagir ${ }^{55}$ stated that interreligious dialogue is not intended to the religion's "conversion", instead to build openness, sincerity and mutual trust as a starting point in responding to various humanitarian issues.

In addition to dialogue, internalizing the values of pluralism is also done with modelling. Educators exemplified about how to appreciate the difference. Because children like to imitate psychologically. Historically, the Prophet successfully instills faith in companions, among them is as exemplary. In the context of religious pluralism, teacher's exemplary is the key in internalizing values to students. However it is important to note that religious education should avoid to: (1) foster the spirit of blind fanaticism, (2) foster intolerance among students and Indonesian citizens; (3) weaken the religious harmony and national unity. ${ }^{56}$ All of this acquire a broad and insight knowledge of the teacher. The higher knowledge and insights they have, the better the tolerance are.

In addition to the teachers, Muhaimin ${ }^{57}$ offers several strategies in order to internalize the values, i.e.: (1) power strategy, the strategy of a civilizing religion in schools by using power or through the people's power, (2) persuasive strategy, which runs through the formation of opinions and views of community or school; and (3) normative re-educative. Norms are the rules that apply in the society which implanted through education. ${ }^{58}$

\section{Students' Understanding on Religious Pluralism.}

Students have a good and different understanding of religious pluralism because of a result of learning process, habituation and

\footnotetext{
${ }^{55}$ JB Banawiratma \& Zainal Abidin Bagir etc. Dialog Antarumat Beragama: Gagasan dan Praktik di Indonesia. Bandung: Mizan, 2010.

${ }^{56}$ Muhaimin. Rekonstruksi..., p. 319.

${ }^{57}$ Ibid., p. 328.

${ }^{58}$ Ibid., p. 328.
} 
school culture. In this context, there are informants who stated that "religious pluralism is the religious diversity in a population", "an attitude of respecting and appreciating the differences of religions without causing disintegration". As the implications of understanding of religious pluralism, hence they have "mutual respect and tolerance of others without distinction or views based on religion".

These statements above imply that the difference in real life is a necessity that must be understood in the reality of life in society, religious diversity is not a barrier to interact with others. The informant expressed:

There are diverse religions, and human beings have the right to choose and believe in religion. We must have tolerance, but try to be unaffected by the other religious customs or cultures in negative things. Absorb the positive things only. But it should not protest / angry at the sight of other things that we disagree to the other religions.

The statement of informant that "religious pluralism was limited to acknowledge its existence, not its truth," meaning that the affiliated religion is the truest religion (truth claims), religious pluralism merely acknowledges its existence, not the truth of its dogma. In addition, some have suggested "religious pluralism is the diversity of people in selecting and implementing religion", also "religious pluralism is the diversity of religions in one place, although there are many religions, we ought to uphold our religion and tolerance with other religions".

According to Fadjar and Arifin ${ }^{59}$, the understanding above that illustrates the notion of normative pluralism and this kind of understanding have not been able to bring a real religious harmony, which still holds the conflict potential. Swidler ${ }^{60}$ also asserted that theologically, it is impossible for believer to assert the truth of others, because as a doctrine, religious beliefs directly relates to belief dimension, which is subjective. Moreover, it contains religious truth claims that may cause potential conflicts, both on the sociological and

\footnotetext{
${ }^{59}$ A.Malik Fadjar \& Syamsul Arifin. "Muhammadiyah dan Pluralisme Agama" Jurnal Ulumuddin No 1, Thn IV, Juli 2001. Malang: FAI Univ. Muhammadiyah. 2001, p. 8.

${ }^{60}$ Leonard Swidler. The Dialogue....,
} 
theological order. Muhaimin ${ }^{61}$ stated that religion has assumption on its need for the believer to have a life way. Therefore, believers will try to position themselves loyally. However, one must also recognize that although there are differences, there are also similarities.

Arifin $^{62}$ said that the integration of a religious pluralism is also influenced by personage. In the study of religion, the teacher becomes a figure that influences students in understanding religious pluralism. Therefore, teachers should be encouraged to improve themselves.

\section{Religious Pluralism in Students's Acquaintance.}

Students of Madania have a different religious background. Students stated that "in school, we have social relationships properly and we appreciate the differences among us". They also stated "we are usual, because everybody has a different belief". It implicitly demonstrates that there is really not barriers to communicate among students who have different religions. In this context, "religious differences that make a person feels different from other" as Fadjar and Arifin ${ }^{63}$ stated, do not occur in Madania High School, because Madania's students do not questionate their socio-religious background. Furthermore, other informant stated that in daily life, they "understand and appreciate the differences in which they are do not discriminated, and unfeel self-righteous."

I am proper, and I do not discriminate the other who have different religions, or I am not care more or I do not love more the others who have same religion. I do not partly choose friends and I am acquintance with others who have different religions, I also recognize the religion they profess, I always appreciate their belief and I do not judge my friends relate to their religion.

Other than that:

\footnotetext{
${ }^{61}$ Muhaimin. Rekonstruksi..., p. 315.

${ }^{62}$ M. Saerozi. Politik Pendidikan Agama dalam Era Pluralisme. Yogyakarta: Tiara Wacana, 2004.

${ }^{63}$ A.Malik Fadjar dan Syamsul Arifin. "Muhammadiyah...,
} 
It is usual, because everyone has different beliefs, and I think that the truth is relative in every religion, nothing is absolute. I respect each trust and their actions. I have moslem and non moslem friends. I do not know why it is, but in my mind, religion is not the most important factor in making friends. I should pay attention. I make them my friends because they are good, not because of their Moslem.

There is a other statement that through different religion friends, person also will have a broader perspective rather than simply fellow religion, he stated:

Act like a good neighbour, help in difficult circumstances, be happy in a happy state. Having a friend with the same religion only will narrow way of thinking.

If we make friends with a different religion, our way of thinking will be broader. But we remain retaining our religious views "to you your religion, to me mine"

These phrases indicate that the socialization can be done with anyone, regardless of background differences, but remain keeping personal religion. Among informant strengthened his argument and cited Sura Al-Nasr: 6, "Yours is your religion, and mine is my religion." Informant said "... with these differences, we can complement each other, it would not hurt to make friends with people of other faiths ".

The views and attitudes of students on religious pluralism is shaped as a result of educational interaction, where it is not sparated from teaching religion in the schools. In this context, the role of the teacher shows a vital force. ${ }^{64}$ Paulo Freire said that "education is not an ivory tower trying to avoid the social and cultural reality." Education should be able to create a society educated, it does not just glorify an amazing community for the wealth and prosperity". Jalaluddin pointed out "religious education in the school, however,

\footnotetext{
${ }^{64}$ Moh. Uzer Usman. Menjadi Guru Profesional. Bandung: PT Remaja Rosdakarya, 1992, p. 3.
} 
will give an impact for forming religious life of the children" 65 , schools should maximize this role, because students' attitudes are formed on the basis of the values they choose. ${ }^{66}$

\section{Conclusion.}

The conclusion of this study, namely: (1) the content of religious education still deepen on "internal", and there has been little discussion related to religious pluralism in the context of diversity, (2) the understanding of teachers, religious differences are natural. But the religion he professes is the only religion, it is the true one, and that truth is absolute, but it still appreciates the differences, (3) Internalizing pluralism values in the teaching of religion was through a dialogue, modelling, and the activities of the interactive interfaith, (4) students understand religious pluralism as a different belief from each individual, and these differences must be respected and honoured, not debatable, because everyone has the right and different belief, (5) the attitude of students' religious pluralism in the association shows openess, the difference of religion is not a barrier to interact with friends who have a different religious background.

\section{REFERENCE}

Abdullah, Amin. 2005, Pendidikan Agama Era Multikulturalisme Multireligius. Jakarta: Pusat Studi Agama dan Peradaban (PSAP) Muhamadiyyah,.

Abdurrahman Moeslim. 1982, "Posisi Berbeda Agama dalam Kehidupan

Sosial di Pedesaan", dalam Mulyanto Sumardi (Penyusun), Penelitian Agama: Masalah dan Pemikiran. Jakarta: Penerbit Sinar Harapan,

Afrizal. "Negara dan Konflik Agraria: Studi Kasus pada Komunitas Pusat Perkebunan Kelapa Sawit Berskala Besar di Sumatera Barat". Masyarakat, Kebudayaan dan Politik. 20 (3), 2007, pp. 89-107. Arikunto, Suharsimi. Prosedur Penelitian. Jakarta: Rineka Cipta, 1997.

\footnotetext{
${ }^{65}$ Jalaluddin. Psikologi Agama. Memahami Perilaku Keagamaan dengan Mengakplikasikan Prinsip-Prinsip Psikologi. Jakarta: PT. Raja Grafindo Persada, 2007, p. 256.

${ }^{66}$ Jalaluddin. Psikologi.., p. 107.
} 
Azizy, A.Qodry A.. 2002, Pendidikan (Agama) untuk Membangun Etika Sosial: Mendidik Anak Sukses Masa Depan, Pandai dan Bermanfaat. Semarang: Aneka Ilmu.

Banawiratma, J.B. \& Zainal Abidin Bagir. 2010, Dialog Antarumat Beragama: Gagasan dan Praktik di Indonesia. Bandung: Mizan.

Brandt, Ronald. "What Do You Mean Professional'?. Educational Leadership. No. 6, (50), March. 1993.

Elizabeth Misbah Zulfa. 2007, "Multi Etnisitas Indonesia dan Potensi Konflik di dalamnya", dalam Musahadi HAM (Ed.). Mediasi dan Resolusi Konflik di Indonesia: dari Konflik Agama hingga Mediasi Peradilan. Semarang: Mediation Centre.

Fadjar, A.Malik dan Syamsul Arifin. 2001, "Muhammadiyah dan Pluralisme Agama", Jurnal Ulumuddin No 1, Thn IV, Juli 2001. Malang: FAI Univ. Muhammadiyah.

Gagne, Robert M.. 1992, Principles of Instructional Desaign. Orlando: Harcourt Brace Jovanovich College Publisher,.

Guuido, De Ruggiero; 1933, "Liberalism” dalam Seligmen Edwin R.A. Encyclopedia of Social Science. New York: The Maccmillan Company.

Heyneman, S.P. dan W.Loxley. 1988, "The Impact of Primary School Quality on Academic Achievement in 29 High and Low Income Countries". American Journal of Sociology, 88.

Huberman, A.M. \& M.B. Miles. 1985, Qualitative Data Analysis: a Sourcebook of New Methods. London: Sage Publications.

Huseen, Fatimah. 2009. "Merangkul yang Lain" dalam Hendri Wijayatsih dkk. Memahami Kebenaran yang Lain sebagai Pembaharuan Hidup Bersama. Yogyakarta: Taman Pustaka Kristen.

J.W. Best. 1982, Metodologi Penelitian Pendidikan. Surabaya: Usaha Nasional.

Jalaluddin. 2007, Psikologi Agama. Memahami Perilaku Keagamaan dengan Mengakplikasikan Prinsip-Prinsip Psikologi. Jakarta: PT. Raja Grafindo Persada.

Jurnal Ulumuddin No. 4 Thn 3, Juni Malang: FAI Univ. Muhammadiyah, 2000.

Kamus Umum Bahasa Indonesia. Jakarta: Balai Pustaka, 1984. 
Lickona, Thomas. Educating for Character: How Our Schools Can Teach Respect and Responsibilty. New York: Bantam Book, 1992.

Madjid, Nurcholish. Mencari Akar-Akar Islam bagi Pluralisme Modern: Pengalaman Indonesia dalam Jalan Baru. Bandung: Mizan, 1998.

Mardapi, Djemari. 2012, Pengukuran, Penilaian dan Evaluasi Pendidikan. Yogjakarta: Nuha Litera.

Mas'ud, Abdurrahman. 2002, Menggagas Format Pendidikan Non Dikotomik: Humanisme Religius sebagai Paradigma Pendidikan Islam. Yogjakarta: Gama Media.

Moeliono, Anton M.. 2008, Kamus Besar Bahasa Indonesia. Jakarta: Balai Pustaka.

Moleong, Lexy J.. 2002, Metodologi Penelitian Kualitatif. Edisi Revisi. Bandung: PT. Remaja Rosda Karya,.

Muhaimin. 2005, Pengembangan Kurikulum Pendidikan Agama Islam di Sekolah, Madrasah dan Perguruan Tinggi. Jakarta: Raja Grafindo Persada.

Musahadi HAM (Ed.). 2007, Mediasi dan Resolusi Konflik di Indonesia: dari Konflik Agama hingga Mediasi Peradilan. Semarang: Mediation Centre.

N. Susan. 2009, Sosiologi Konflik dan Isu -Isu Konflik Kontemporer. Jakarta: Prenada Media Group.

Nasr, Seyyed Hussein. (1994). Ideal and Realities of Islam. Lahore: Suhail Academic

Oladipo, S.E.. (2009). "Moral Education of the Child: Whose Responsibility?", J Sec Sei, 20, (2).

Rachman, Budi Munawar. Islam Pluralis. Jakarta: Paramadina, 2001.

Ritzer, George, dan Douglas J. Goodman. 2010, Teori Sosiologi: Dari Teori Sosiologi Klasik Sampai Postmodern. Terj. Nurhadi. Yogyakarta: Kreasi Wacana.

Saerozi, M.. 2004, Politik Pendidikan Agama dalam Era Pluralisme. Yogyakarta: Tiara Wacana.

Salim, Agus. 2006, Teori dan Paradigma Penelitian Sosial. Yogyakarta: Tiara Wacana.

Shihab, Alwi. 1999, Islam Inklusif Menuju Sikap Terbuka. Bandung: Mizan,. 
Siahaan, H.. 2002, "Karakteristik dan Faktor Pemicu Konflik di Daerah Jawa Timur". Masyarakat, Kebudayaan dan Politik. 15(1),

Suhadi Cholil dkk. 2013, Laporan Tahunan Kehidupan Beragama di Indonesia 2012. Yogyakarta: Central for Religious Cross-cultural Studies (CRCS) UGM..

Susetiawan. Konflik Sosial, Kajian Sosiologis Hubungan Buruh, Perusahaan dan Negara di Indonesia. Yogyakarta: Pustaka Pelajar, 2000.

Swidler, Leonard. "The Dialogue Decalogue; Ground Rules for Interreligious, Interidioligical Dialogue", Journal of Ecumenical Studies. Vol. 20 (01). 1984.

Syahroni A.J. "Pluralisme Keberagamaan: Wawasan Subyek Dakwah", Wacana, No. 1, Vol. 3, November 2003. Surabaya: Kopertais Wilayah IV, 2003.

Thoha, Anis Malik. 2007, Tren Pluralisme Agama: Tinjauan Kritik. Jakarta: Perspektif Kelompok Gema Insani.

Tilaar, HAR \& R Nugroho. 2008, Kebijakan Pendidikan. Yogyakarta: Pustaka Pelajar,.

Tim. Madania Indonesian School With World Class Sandard. Bogor. Madania, t.t.

Usman, Moh. Uzer. 1992, Menjadi Guru Profesional. Bandung: PT Remaja Rosdakarya.

Yin, Robert K.. 1994, Case Study Research: Design and Methods. Newbury Park CA: Sage Publication,.

Yuwinant,o H.P.. 2004, “Konflik Antar Etnik di Pedesaan”. Masyarakat, Kebudayaan dan Politik. 17 (3),

UNESCO. Learning to Be. Paris: UNESCO, 1972.

UU No.20 Tahun 2003 tentang Sistem Pendidikan Nasional.

UU.No.12 Tahun 2012 tentang Perguruan Tinggi. 